\title{
Determinants of Non-Adherence to Treatment Among Patients with Type 2 Diabetes in Kenya: A Systematic Review
}

\author{
Brian Barasa Masaba (D) \\ Rose M Mmusi-Phetoe \\ University of South Africa, Pretoria, \\ South Africa
}

This article was published in the following Dove Press journal: Journal of Multidisciplinary Healthcare
Introduction: Non-adherence to the prescribed treatment regimen in patients with type 2 diabetes mellitus is quite high. Furthermore, it has been associated with higher rates of hospital admissions, suboptimal health outcomes, increased morbidity and mortality, and increased health care costs. The present systematic review study aimed to explore the determinants that contribute to non-adherence to treatment among patients with type 2 diabetes mellitus in Kenya.

Methods: A systematic review of studies conducted in Kenya on the present research problem published in English between December 2013 and May 2020. The databases included Scopus, Web of Science, Science Direct, Cochrane Library, PUBMED, OVID and Google Scholar. The following were the key words used in the search: "Nonadherence Diabetes Patients", "Determinants of Non-adherence Diabetes Patients" AND "Health Facilities" AND "Kenya". Qualitative analysis was used to present data under thematic domains.

Results: The search generated 17,094 articles of which only 15 met the inclusion criteria. The major determinants were presented under three thematic domains: 1) Cost - income, insurance, distance, bills of drugs and food; 2) Patient characteristics - perception of (efficacy, severity, effects of non-adherence), knowledge, co-morbidity, family support, self unfounded beliefs; and 3) Health system - health education, multiple drugs, evaluations and support, guidelines, poor perception of system.

Conclusion: A multitude of factors including unaffordable care, patient's poor knowledge on the disease process, less family support in patient's daily self-care management, complex drug regimen and unsatisfactory health messages from the health providers were observed to be associated with non-adherence. Implementing integrated care programs will help in reducing levels of non-adherence among type 2 diabetes mellitus patients.

Keywords: diabetes mellitus, humans, hypoglycemic agents, Kenya, medication adherence, type 2

\section{Introduction}

Diabetes mellitus (DM) is a chronic metabolic disorder characterized by persistent hyperglycemia. ${ }^{1}$ Diabetes mellitus (Type 1 and 2) is a significant and growing health problem worldwide. ${ }^{2}$ Recently the International Diabetes Federation (IDF) estimated that 463 million people had diabetes in $2019 .^{3}$ IDF projects that without urgent and sufficient actions, 578 million people will have diabetes in 2030 and the number will increase by $51 \%$ (700 million) in $2045 .^{3}$ According to World Health
Correspondence: Brian Barasa Masaba Email 637I4094@mylife.unisa.ac.za 
Organization reports, an estimated 1.6 million deaths were directly caused by diabetes in $2016 .{ }^{4}$ In Kenya, noncommunicable diseases (NCD's), of which diabetes is among the leading, are important sources of morbidity and mortality. ${ }^{5}$ Current population based studies in both rural and urban Kenya have reported a diabetes prevalence of $3.5-5 \%$, with higher proportions among those in the urban areas. ${ }^{6}$

Type 2 diabetes - previously referred to as non-insulin dependent or maturity onset diabetes - this type results from failure of the pancreas to produce adequate insulin or failure of body cell to utilize insulin or both. ${ }^{1}$ It accounts for about $85-90 \%$ of all cases of diabetes. ${ }^{7}$ Type 2 diabetes can lead to complications in many parts of the body and can increase the overall risk of dying prematurely. ${ }^{8}$ Possible complications include heart attack, stroke, kidney failure, leg amputation, vision loss and nerve damage. ${ }^{8}$

Type 2 diabetes requires long-term follow up, with uninterrupted access to medication and specialist care. ${ }^{9}$ Additionally comprehensive care for a type 2 diabetes patient includes regular blood glucose monitoring, exercise, dietary modification, the use of anti-diabetic drugs, which are necessary for disease control and regular screening for damage to the eyes, kidneys and feet, to facilitate early treatment. ${ }^{8,10}$ Maintaining good glycemic control measured by glycated hemoglobin (HbAlc) is believed to allow patients to maintain insulin production and reduce insulin resistance. ${ }^{11}$ The American Diabetes Association (ADA) recommends those diagnosed with type 2 diabetes receive diabetes self-management education and support, including training to improve diabetes knowledge and selfcare behaviors as well as clinical care to support glycemic control. $^{12}$

At least $45 \%$ of patients with type 2 diabetes mellitus (T2DM) fail to achieve adequate glycemic control (HbA $1 \mathrm{c}<7 \%)$ and one of the major contributing factors is poor treatment adherence. ${ }^{13}$ Diabetes medication adherence and hemoglobin A1c appear to be inversely related. ${ }^{14}$ Achieving glycemic control and preventing early complications are the ultimate targets of diabetes management which depends on patient's adherence to regimens. ${ }^{15}$ Poor medication adherence makes achieving good glycemic control difficult, which is believed to affect the onset of diabetic microangiopathy (retinopathy, nephropathy, and neuropathy) and increase the risk of diabetic complications. ${ }^{11,16}$ Furthermore non-adherence is associated with higher rates of hospital admissions, suboptimal health outcomes, increased morbidity and mortality, and increased health care costs. ${ }^{17}$ In Brazil, a study on treatment adherence and its associated factors in patients with type 2 diabetes noted that the presence of peripheral neuropathy was associated with worse physical activity adherence. ${ }^{18}$

Adherence has been defined as "the extent to which a person's behavior - taking medication, following a diet, and/or executing lifestyle changes - corresponds with agreed recommendations from a health care provider."19 While non-adherence has been defined as taking $<80 \%$ of the prescribed treatment. ${ }^{20}$ Nonadherence to prescribed treatment regimen in patients with $\mathrm{DM}$ is quite high. $^{21}$ It is a serious concern that poses a great challenge to the successful delivery of healthcare. ${ }^{22}$ For instance in Kenyan studies, low levels of non-adherence to both pharmacological ${ }^{23,24}$ and nonpharmacological $^{25}$ treatment among T2DM patients has been noted. An investigation among T2DM patients on follow-up at Moi Teaching and Referral Hospital (Kenya) showed that the majority of the patients (72\%) had poor compliance to drug treatment. ${ }^{24}$ While Muhabuura's and Mugo's studies demonstrated lower rates of non-adherence to diet and exercise recommendations amongst people diagnosed with T2DM in Nairobi ${ }^{26}$ and Nakuru, Kenya. ${ }^{25}$

Treatment adherence is a complex behavior influenced by factors along the continuum of care, relating to the patient, providers, and health systems. ${ }^{17}$ Multiple factors have been associated with non-adherence among patients with T2DM in Kenya. ${ }^{27,28}$ For example; Ngari et $\mathrm{al}^{28}$ in Meru noted that level of income, affordability of services, health insurance cover of the patients, and monthly cost of DM management significantly influenced non-adherence. ${ }^{28}$ In Nairobi, dissatisfaction with family members support, challenge in drug access and dissatisfaction with attending clinicians were factors found associated with poor medication adherence. ${ }^{29}$ Similarly, Mwaloma's ${ }^{30}$ study noted that the majority of the patients with low adherence levels were not sufficiently equipped with knowledge with attending clinicians to comprehensively manage their disease. ${ }^{30}$ Adherence to treatment can be improved by analyzing the different associated determinants. The question adopted in the present systematic review study was; what are the determinants that contribute to nonadherence to treatment among patients with T2DM in Kenya? 


\section{Methodology}

A systematic review design was utilized to conduct the present study.

\section{Eligibility Criteria}

Eligibility criteria of the selected articles were based on the following: 1) studies conducted in Kenya on the present research problem; and 2) studies published in English between December 2013 and May 2020. In addition, no restriction was made to the study designs used in the articles selected in order to increase the sample. In the present study, treatment was defined as medical care (both pharmacological and non-pharmacological) provided to patients with type 2 diabetes.

\section{Exclusion Criteria}

Duplicates, unavailable full-paper articles and abstractonly articles were excluded.

\section{Information Sources}

A systematic search in the following databases: Scopus, Web of Science, Science Direct, Cochrane Library, PUBMED, OVID and Google scholar was used. The key words used in the search were as follows; "Non-adherence Diabetes Patients," "Determinants of Non-adherence Diabetes Patients" AND "Health Facilities" AND "Kenya." Other literature sources were found after screening of all the references of all the added papers. Prior to the development of search terms, we looked for appropriate MeSH terms and applied them with maximal truncations.

\section{Study Selection}

The downloaded articles were screened and selected by two independent researchers (BBM \& RMP) guided by the eligibility criterion that was initially set. The researchers developed datasets of the selected articles. Data was extracted from the selected studies. Any disagreement on article selection was resolved by consensus between the two researchers.

\section{Synthesis of Results}

This was a secondary analysis and all identifiers of the individual participants were removed or presented using unique codes. This study adopted PRISMA (Figure 1) reporting as demonstrated previously. ${ }^{31}$ Data was presented and organized under three thematic domains: 1) cost - income, insurance, distance, bills of drugs and food; 2) patient characteristics - perception of (efficacy, severity, effects of non-adherence), knowledge, comorbidity, family support, self unfounded beliefs; and 3) health system - health education, multiple drugs, evaluations and support, guidelines, poor perception of system.

\section{Results}

The search generated 17,094 articles of which 83 duplicate articles were removed. After the screening process of their titles and abstracts only 21 articles were identified and were thereafter included in the full text review. The identified articles were further assessed using the adopted inclusion criteria. Among 21 articles only 15 met the inclusion criteria. According to Table 1, the specific study settings of the articles utilized were as follows; six studies were conducted in Nairobi, three studies in Eastern Kenya, three in Western Kenya and finally three in the Rift valley region. All the studies reviewed had their study settings in a hospital. The majority (12/15) of the studies adopted a descriptive cross-sectional study design in their methodology apart from two that had retrospective designs and one study that utilized a longitudinal design as shown in Table 1. Study participants were patients with T2DM being managed by the respective hospitals in the studies. All the study participants were above 18 years of age. Data was presented and organized under three thematic domains: 1) cost; 2) patient characteristics; and 3) health system.

\section{Cost (Income, Insurance, Distance, Bills of Drugs and Food)}

The majority of the patients complained of the cost of drugs and the diet recommended being unaffordable ${ }^{23,24,27-29}$ and unavailable. ${ }^{25}$ Long distance to the hospital was noted as a barrier to the regular check-ups needed by the patients. ${ }^{30}$ The unaffordable cost of gluco-strips was a hindrance to the self-monitoring of blood glucose by the patients. ${ }^{32}$

\section{Patient Characteristics (Perception of [Efficacy, Severity, Effects of Non-Adherence], Knowledge, Co-Morbidity, Family Support, Self Unfounded Beliefs)}

Some patients had poor knowledge on the cause of the disease and the self care management required. ${ }^{33}$ For example some noted that the disease comes from $\operatorname{God}^{23,34}$ while others complained of the recommended diet not being acceptable by their religion. ${ }^{35}$ Patients who had higher formal 


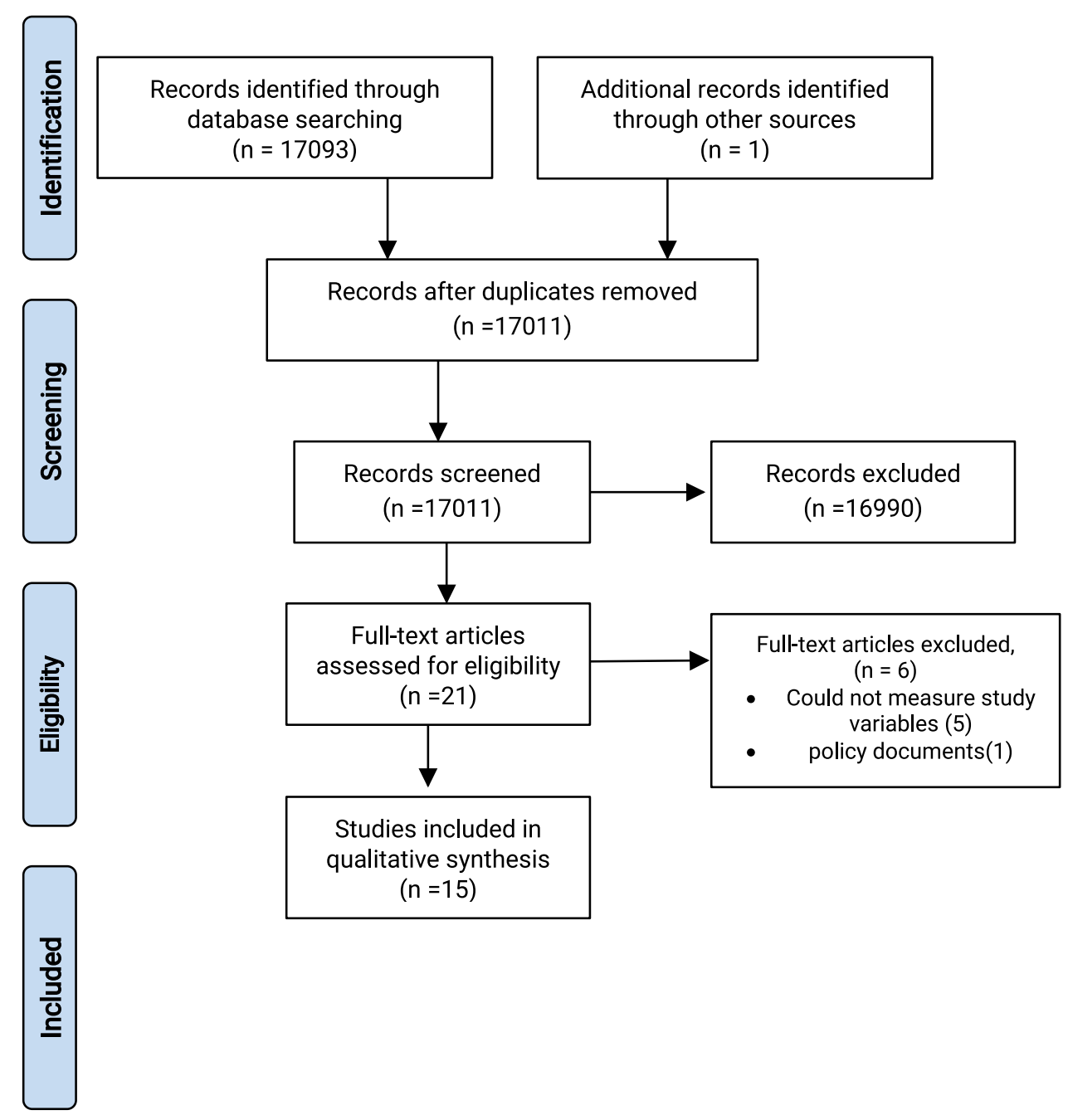

Figure I Description of the PRISMA flow diagram.

Note: Adapted from Liberati A, Altman DG, Tetzlaff J, et al. The PRISMA Statement for Reporting Systematic Reviews and Meta-Analyses of Studies That Evaluate Health Care Interventions: Explanation and Elaboration. Ann Intern Med. 2009;15I(4):65-94. ${ }^{31}$

education reported to adhere well with the recommended diet than their counterparts. ${ }^{25}$ Lack of family support either by encouragement to the patient or by preparing meals advocated was noted in some studies. ${ }^{24,25,29}$ Alcohol drinking behavior ${ }^{35}$ was revealed as a cause of non-adherence. Some patients believed in traditional healing methods for diabetes. ${ }^{28}$ Patients withdrew from treatment when they felt better. ${ }^{34}$ Severity of illness ${ }^{26}$ hindered exercise adherence.

\section{Health System (Health Education,} Multiple Drugs, Evaluations and Support, Guidelines, Poor Perception of System)

Health system failures were noted by the participants as a reason for their non-adherence. ${ }^{26}$ For instance, patients complained of long turn-around times, unsatisfactory health messages being offered, unsatisfactory care by the attending clinician, poor adherence to diabetes guidelines by healthcare professionals at the hospital and unavailability of the drugs within the hospitals. ${ }^{23,29,36}$ In Mwaloma's study health education is self sponsored by the patient. ${ }^{30}$ On the other hand Theuri et al's study provides evidence of how use of mobile phone communication increased adherence to diabetes medication. ${ }^{37}$

\section{Discussion}

The present systematic review study aimed to explore the determinants that contribute to non-adherence to treatment among patients with T2DM in Kenya. The findings were organized under three thematic domains: 1) cost; 2) patient characteristics; and 3) health system.

\section{Cost Factors}

This study revealed that unaffordable care and indirect fees related to the costs of seeking health care such as transport 
Table I Description of the Studies Reviewed

\begin{tabular}{|c|c|c|c|c|c|}
\hline $\begin{array}{l}\text { Study } \\
\text { (Reference) }\end{array}$ & Study Setting & Period & Participants & Design & Results \\
\hline $\begin{array}{l}\text { (Koech, } \\
\text { Nguka, \& } \\
\text { Oloo, 2019) }\end{array}$ & $\begin{array}{l}\text { Moi Teaching and } \\
\text { Referral Hospital }\end{array}$ & 2019 & $\begin{array}{l}137 \text { ( } 51.8 \% \text { female and } \\
48.2 \% \text { male })\end{array}$ & $\begin{array}{l}\text { Descriptive } \\
\text { cross- } \\
\text { sectional } \\
\text { design }\end{array}$ & $\begin{array}{l}\text { Patient's occupation was a significant variable } \\
\text { associated to adherence. }\end{array}$ \\
\hline $\begin{array}{l}\text { (Sakari \& } \\
\text { William, } \\
\text { 2019) }\end{array}$ & $\begin{array}{l}\text { Butere subcounty } \\
\text { Hospital }\end{array}$ & 2019 & $\begin{array}{l}\text { Total of } 71 \text { patients } \\
\text { participated, } 47.8 \% \text { were } \\
\text { males }\end{array}$ & $\begin{array}{l}\text { Cross } \\
\text { sectional } \\
\text { study }\end{array}$ & $\begin{array}{l}\text { Poor knowledge in these patients was } \\
\text { associated with unsatisfactory glycemic } \\
\text { control. }\end{array}$ \\
\hline $\begin{array}{l}\text { (Theuri, } \\
\text { Makokha, \& } \\
\text { Kyallo, 2019) }\end{array}$ & $\begin{array}{l}\text { Kitui County } \\
\text { Referral Hospital. }\end{array}$ & 2019 & $\begin{array}{l}\text { I } 38 \text { (male } 34.3 \% \text { female } \\
65.7 \%)\end{array}$ & $\begin{array}{l}\text { Longitudinal } \\
\text { study }\end{array}$ & $\begin{array}{l}\text { Use of mobile phone communication increased } \\
\text { adherence to diabetes medication in the } \\
\text { aspects of no delayed and missed doses }\end{array}$ \\
\hline $\begin{array}{l}\text { (Ngari, Mbisi, } \\
\text { \& Njogu, } \\
\text { 2020) }\end{array}$ & $\begin{array}{l}\text { Consolata Hospital } \\
\text { Nkubu and Meru } \\
\text { Level Five Hospital }\end{array}$ & 2019 & 357 participants & $\begin{array}{l}\text { A descriptive } \\
\text { correlational } \\
\text { study design }\end{array}$ & $\begin{array}{l}\text { Level of income, affordability of services, health } \\
\text { insurance cover of the patients, and monthly } \\
\text { cost of DM management significantly } \\
\text { influenced non-adherence. }\end{array}$ \\
\hline $\begin{array}{l}\text { (Kathomi, } \\
2018)\end{array}$ & $\begin{array}{l}\text { Meru Teaching and } \\
\text { Referral Hospital }\end{array}$ & 2018 & $\begin{array}{l}\text { I57 adults } 19 \text { years and } \\
\text { above }\end{array}$ & $\begin{array}{l}\text { A cross- } \\
\text { sectional } \\
\text { analytical } \\
\text { study design }\end{array}$ & $\begin{array}{l}\text { Patients co-morbidities influenced adherence } \\
\text { levels }\end{array}$ \\
\hline (Mugo, 2018) & $\begin{array}{l}\text { Three sub-county } \\
\text { hospitals and } \\
\text { Nakuru County } \\
\text { Referral hospital }\end{array}$ & 2018 & $\begin{array}{l}387 \text { (male } 34.9 \% \text { female } \\
65.1 \%)\end{array}$ & $\begin{array}{l}\text { Cross- } \\
\text { sectional } \\
\text { analytical } \\
\text { study }\end{array}$ & $\begin{array}{l}\text { Respondents reported financial constraints } \\
(47 \%) \text { as a major hindrance to compliance to } \\
\text { recommended dietary practices. }\end{array}$ \\
\hline $\begin{array}{l}\text { (Mwaloma, } \\
2016)\end{array}$ & $\begin{array}{l}\text { Kenyatta National } \\
\text { Hospital }\end{array}$ & 2016 & $\begin{array}{l}105 \text { women aged } 50 \text { years } \\
\text { and above }\end{array}$ & $\begin{array}{l}\text { Cross- } \\
\text { sectional, } \\
\text { descriptive } \\
\text { study design. }\end{array}$ & $\begin{array}{l}\text { Significant barriers are the cost of care, and the } \\
\text { availability of suitable care within a reasonable } \\
\text { distance (ie, geographic barriers). }\end{array}$ \\
\hline (Maina, 2016) & Mbagathi Hospital & 2016 & $\begin{array}{l}\text { II } 3 \text { (females } 61.9 \% \text { and } \\
\text { males } 38.1 \% \text { ) }\end{array}$ & $\begin{array}{l}\text { A descriptive } \\
\text { cross- } \\
\text { sectional } \\
\text { study }\end{array}$ & $\begin{array}{l}\text { Non-adherence was associated with use of } \\
\text { multiple oral diabetic medications }\end{array}$ \\
\hline $\begin{array}{l}\text { (Mugah \& } \\
\text { Muhati, 2016) }\end{array}$ & $\begin{array}{l}\text { Vihiga District } \\
\text { Hospital. }\end{array}$ & 2016 & 122 respondents & $\begin{array}{l}\text { Descriptive } \\
\text { study }\end{array}$ & $\begin{array}{l}\text { Certain cultural practices such as controversial } \\
\text { religious beliefs, associating the diabetic with } \\
\text { witchcraft or attributing it as a preserve for the } \\
\text { rich similarly interferes with the control and } \\
\text { management of the disease. }\end{array}$ \\
\hline $\begin{array}{l}\text { (Waari, Mutai, } \\
\text { \& Gikunju, } \\
2018)\end{array}$ & $\begin{array}{l}\text { Kenyatta National } \\
\text { Hospital }\end{array}$ & 2016 & 290 participants & $\begin{array}{l}\text { A cross- } \\
\text { sectional } \\
\text { study }\end{array}$ & $\begin{array}{l}\text { Dissatisfaction with family members support } \\
\text { was associated with poor medication } \\
\text { adherence }\end{array}$ \\
\hline $\begin{array}{l}\text { (Musee, } \\
\text { Okeyo, \& } \\
\text { Odiwuor, } \\
2016)\end{array}$ & $\begin{array}{l}\text { Jaramogi Oginga } \\
\text { Odinga Teaching } \\
\text { and Referral } \\
\text { Hospital, Kisumu }\end{array}$ & 2016 & $\begin{array}{l}240 \text { adults } 35 \text { years and } \\
\text { above }\end{array}$ & $\begin{array}{l}\text { Cross- } \\
\text { sectional } \\
\text { study design }\end{array}$ & $\begin{array}{l}\text { Socio-economic factors had an influence on the } \\
\text { adherence domains }\end{array}$ \\
\hline
\end{tabular}

(Continued) 
Table I (Continued).

\begin{tabular}{|l|l|l|l|l|l|}
\hline $\begin{array}{l}\text { Study } \\
\text { (Reference) }\end{array}$ & Study Setting & Period & Participants & Design & Results \\
\hline $\begin{array}{l}\text { (Asenahabi, } \\
2014)\end{array}$ & $\begin{array}{l}\text { Kenyatta National } \\
\text { Hospital }\end{array}$ & 2014 & Total of I99 participants & $\begin{array}{l}\text { Cross- } \\
\text { sectional } \\
\text { study }\end{array}$ & $\begin{array}{l}\text { Affordability of care and knowledge were } \\
\text { associated to compliance to treatment }\end{array}$ \\
\hline $\begin{array}{l}\text { (Atienojalang, } \\
\text { Tsolekile, \& } \\
\text { Puoane, 20I4) }\end{array}$ & $\begin{array}{l}\text { Kenyatta ational } \\
\text { Hospital. }\end{array}$ & 2014 & 377 outpatient files & $\begin{array}{l}\text { Retrospective } \\
\text { study }\end{array}$ & Low quality of care from health providers \\
\hline $\begin{array}{l}\text { (Muhabuura, } \\
2014)\end{array}$ & $\begin{array}{l}\text { Kenyatta National } \\
\text { hospital (KNH) } \\
\text { diabetic clinic, }\end{array}$ & 2014 & $\begin{array}{l}\text { Of the 324 participants, } \\
50.62 \%(\mathrm{n}=164) \text { were } \\
\text { female and 49.38\% }(\mathrm{n}=160) \\
\text { were male. } \\
\text { All above } 28 \text { years }\end{array}$ & $\begin{array}{l}\text { A descriptive } \\
\text { cross- } \\
\text { sectional } \\
\text { study }\end{array}$ & $\begin{array}{l}\text { Weather, sickness, lack of written instructions } \\
\text { regarding exercise and healthy dietary habits } \\
\text { from health care provider, and lack of social } \\
\text { support were significant reasons for non- } \\
\text { adherence. }\end{array}$ \\
\hline $\begin{array}{l}\text { (Charity et al, } \\
2015)\end{array}$ & $\begin{array}{l}\text { Moi Teaching and } \\
\text { Referral Hospital, }\end{array}$ & 2013 & $\begin{array}{l}\text { Of I64 patients }(59 \% \\
\text { female; }(21-55) \text { years. }\end{array}$ & $\begin{array}{l}\text { Retrospective } \\
\text { cohort study }\end{array}$ & $\begin{array}{l}\text { Adherence to self-monitoring of blood glucose } \\
\text { was sub-optimal }\end{array}$ \\
\hline
\end{tabular}

costs were key determinants to non-adherence to treatment among patients with T2DM. This implies that most of the patients were not socioeconomically stable and had no medical insurance covers. This made them unable to buy the medications needed, the foods recommended, and make regular visits to the hospital ${ }^{38}$. This is supported by similar studies in Sudan, ${ }^{39}$ Cameroon $^{40}$ and the United States of America. ${ }^{13}$

\section{Patient Characteristic Factors}

The study demonstrated that patients adhered well if they knew of the effects of non-adherence, had knowledge on the disease process, had family support in their daily selfcare management and were not taking excessive alcohol. For instance patients reported not following the given recommendations on the diet as they found the food to be unpalatable. Being encouraged by friends and family improved the adherence levels. Interestingly, some patients reported using traditional herbs in their self care management. Corroborating these findings, Divya and Nadig's study in India noted that the majority $(71.9 \%)$ of patients with T2DM were not aware of what happens on missing medications regularly. ${ }^{22}$ Patients in the present study were noted to willingly stop the treatment plan because of their improvement in health or side effects of the drug. Elsewhere in an Asian study researchers noted that willingness to avoid side effects were common reasons of nonadherence. $^{41}$ In Iran, Benrazavy and Khalooei's study showed that education level was the most important predicting factor of adherence to medication. ${ }^{10}$

\section{Health System Factors}

The patients showed poor adherence when they were served with multiple drugs and when the health providers were unsatisfactory in their health messages on self care. In addition, patients had low adherence levels if they rated poorly the hospital or the drugs were out of stock. Unexpectedly, some patients noted that they were charged for the health messages received; making this unaffordable. Previously in an Indian study on non-adherence, the researchers revealed that $64.6 \%$ of the patients with T2DM lacked information about prescribed medications demonstrating that no health education was given, ${ }^{22}$ while in Nigeria, $88.4 \%$ of the patients with T2DM were not aware of the indication for their prescribed medications. ${ }^{42}$ Similar trends were noted in a study in Sudan ${ }^{39}$ and Asia. ${ }^{41}$ Not surprisingly, treatment adherence becomes more challenging when the treatment itself is perceived as more difficult, onerous, or burdensome. $^{13}$ In Iran it was found that non-adherence among patients with T2DM was influenced by lack of a deep understanding of the medical knowledge on diabetes in many aspects, and those who had little faith in doctors' prescriptions and recommendations. ${ }^{43}$ Appropriate health education and counseling should improve the adherence rate as noted in Nigeria. ${ }^{44}$

\section{Conclusion}

The majority of T2DM patients have suboptimal treatment adherence which is associated with poor blood sugar control. The present review noted that, the major determinants to non-adherence to treatment among patients with T2DM 
are; unaffordable care, patient's poor knowledge on the disease process, less family support in patient's daily selfcare management, poly-pharmacy drug prescriptions and unsatisfactory health messages from the health providers. The study calls out for sustainable integrated care initiatives to improve treatment adherence among T2DM patients.

\section{Limitation}

The studies reviewed used different methodological approaches in measuring the non-adherence level in the patients and this hindered the researchers from measuring the prevalence levels within this study.

\section{Abbreviations}

$\mathrm{DM}$, diabetes mellitus; $\mathrm{Hb}$ A1C, glycated hemoglobin this test gives an average of blood glucose over the last 2 to 3 months. Patients with an $\mathrm{Hb} \mathrm{A} 1 \mathrm{C}$ greater than $6.5 \%$ (48 $\mathrm{mmol} / \mathrm{mol}$ ) are diagnosed as having DM; T2DM, type 2 diabetes mellitus.

\section{Acknowledgments}

The authors would like to extend their gratitude to the librarians who helped them to access information resources at The University of South Africa (UNISA); South Africa.

\section{Author Contributions}

All authors contributed to data analysis, drafting or revising the article, have agreed on the journal to which the article will be submitted, gave final approval of the version to be published, and agree to be accountable for all aspects of the work.

\section{Funding}

The researchers were granted research funds by the University of South Africa, which supported the present study.

\section{Disclosure}

The authors report no conflicts of interest in this work.

\section{References}

1. Goyal R, Jialal I. Diabetes Mellitus Type 2. New York: StatPearls; 2020.

2. Rwegerera GM. Adherence to anti-diabetic drugs among patients with Type 2 diabetes mellitus at Muhimbili National Hospital, Dar es Salaam, Tanzania - a cross-sectional study. Pan African Med J. 2014;8688:1-9. doi:10.11604/pamj.2014.17.252.2972
3. Saeedi P, Petersohn I, Salpea P, et al. Global and regional diabetes prevalence estimates for 2019 and projections for 2030 and 2045: results from the International Diabetes Federation Diabetes Atlas, 9 th edition. Diabetes Res Clin Pract. 2019;157:107843. doi:10.1016/j. diabres.2019.107843

4. WHO. Diabetes. Geneva: World Health Organization; 2020.

5. El-busaidy H, Dawood M, Kasay A, Mwamlole C, Koraya N. How serious is the impact of Type II Diabetes in Rural Kenya? Open Diabetes J. 2014;7:1-4. doi:10.2174/1876524601407010001

6. Mohamed SF, Mwangi M, Mutua MK, et al. Prevalence and factors associated with pre-diabetes and diabetes mellitus in Kenya: results from a national survey. BMC Public Heal 2018. 2018;18(Suppl 3):1-11.

7. WDF. Kenya National Diabetes Strategy 2010-2015. Denmark: World Diabetes Foundation; 2016.

8. WHO. Global Report on Diabetes. Geneva: World Health Organization; 2016.

9. Jones TLE. Diabetes mellitus: the increasing burden of disease in Kenya. South Sudan Med J. 2013;6(3):59-68.

10. Benrazavy L, Khalooei A. Medication adherence and its predictors in type 2 diabetic patients referring to urban primary health care centers in Kerman City, Southeastern Iran. Shiraz E-Med J. 2019;20:7. doi:10.5812/semj.84746.Research

11. Horii T, Momo K, Yasu T, Kabeya Y, Atsuda K. Determination of factors affecting medication adherence in type 2 diabetes mellitus patients using a nationwide claim-based database in. PLoS One. 2019;14(10):1-12.

12. Walker RJ, Smalls BL, Egede LE. Social determinants of health in adults with Type 2 diabetes - contribution of mutable and immutable factors. Diabetes Res Clin Pr. 2016;110(2):193-201.

13. Polonsky WH, Henry RR. Poor medication adherence in type 2 diabetes: recognizing the scope of the problem and its key contributors. Dovepress Open. 2016;1299-1307.

14. Egede Leonard E, Gebregziabher M, Dismuke Clara E, Lynch Cheryl P. Medication nonadherence in diabetes. Epidemiol Serv $R$ Esearch. 2012;35:2533-2543.

15. Elsous A, Radwan M, Al-Sharif H, Mustafa AA. Medications adherence and associated factors among patients with type 2 diabetes mellitus in the Gaza Strip, Palestine. Front Endocrinol (Lausanne). 2017;8:(June):1-9. doi:10.3389/fendo.2017.00100

16. Marín-peñalver JJ, Martín-timón I, Sevillano-collantes C, Cañizogómez FJ. Update on the treatment of type 2 diabetes mellitus. World J Diabetes. 2016;7(17):354-395. doi:10.4239/wjd.v7.i17.354

17. Neiman A, Ruppar T, Ho M. CDC grand rounds improving medication adherence for chronic disease management. Innov Oppor. 2017;66.

18. Marinho FS, Moram CBM, Rodrigues PC, Leite NC, Salles GF, Cardoso CRL. Treatment adherence and its associated factors in patients with type 2 diabetes: results from the Rio de Janeiro Type 2 Diabetes Cohort Study. J Diabetes Res. 2018;8970196.

19. Ganiyu AB, Mabuza LH, Malete NH, Govender I, Ogunbanjo GA, Health P. Non-adherence to diet and exercise recommendations amongst patients with type 2 diabetes mellitus attending Extension II Clinic in Botswana. Afr J Prm Heal Care Fam Med. 2013;5(1):2-7.

20. Dehdari L, Dehdari T. The determinants of anti-diabetic medication adherence based on the experiences of patients with type 2 diabetes. Arch Public Heal. 2019;77(21):1-9.

21. Riaz M, Basit A, Fawwad A, Ahmedani M, Rizv ZA. Factors associated with non-adherence to Insulin in patients with Type-1 diabetes. 2014;30(2):11-13.

22. Divya S, Nadig P. Factors contributing to non-adherence to medication among type 2 diabetes mellitus in patients attending tertiary care hospital in South India. Asian J Pharm Clin Res. 2015;8 (2):8-10.

23. Maina EW. Factors Associated with Non-Adherence to Oral Hypoglycemic Medications Among Adult Type 2 Diabetes Mellitus Outpatients Attending Mbagathi District Hospital Nairobi, Kenya. Jomo Kenyatta Univ Agric Technol; 2016. 
24. Koech C, Nguka G, Oloo PAJ. Factors affecting treatment compliance among type 2 diabetes patients on follow-up at Moi Teaching \& Referral Hospital. J Heal Med Nurs. 2019;4(5):1-11.

25. Mugo IM. Compliance to Recommended Dietary Practices Among Patients with Type 2 Diabetes Mellitus Attending Selected Hospitals in Nakuru County. Kenyatta Univ; 2018.

26. Muhabuura MB. Prevalence and Factors Associated with Non Adherence to Diet and Exercise Lifestyle Recommendations Among Type 2 Diabetic Patients. Univ Nairobi; 2014.

27. Musee NC, Okeyo DO, Odiwuor W. Key factors on the spotlight as predictors of dietary adherence among patients living with Type 2 diabetes. Eur J Prev Med. 2016;4(5):106-112. doi:10.11648/j. ejpm.20160405.11

28. Ngari DM, Mbisi AM, Njogu TW. Social cultural and economic factors affecting the practice of secondary prevention among patients with Type 2 diabetes mellitus at Consolata Nkubu and Meru Level Five Hospital in Meru County. Open $J$ Clin Diagnostics. 2020;10:1-17. doi:10.4236/ojcd.2020.101001

29. Waari G, Mutai J, Gikunju J. Medication adherence and factors associated with poor adherence among type 2 diabetes mellitus patients on follow-up at Kenyatta National Hospital, Kenya. Pan African Med J. 2018;29(82):1-15.

30. Mwaloma esta mlale. Factors Affecting Type 2 Diabetes Management Amongst Out-Patient Diabetic Women Aged 50 Years and Above at Kenyatta National Hospital, Kenya. Jomo Kenyatta Univ Agric Technol; 2016.

31. Liberati A, Altman DG, Tetzlaff J, et al. The PRISMA statement for reporting systematic reviews and meta-analyses of studies that evaluate health care interventions: explanation and elaboration. Ann Intern Med. 2009;151(4):65-94. doi:10.7326/0003-4819-1514-200908180-00136

32. Charity KW, Kumar AMV, Gudmund S, Chinnakali P, Pastakia SD, Kamano J. Do diabetes mellitus patients adhere to self-monitoring of blood glucose (SMBG) and is this associated with glycemic control? Experiences from a SMBG program in western Kenya. Diabetes Res Clin Pract. 2015;112:37-43. doi:10.1016/j.diabres.2015.11.006

33. Sakari FL, William KK. Utilization of diabetes knowledge and glycemic control, a case of Butere subcounty hospital, Kakamega County, Kenya. Asian J Res Reports Endocrinol. 2019;2(1):1-10.
34. Kathomi mugambi terry. Dietary Practices, Physical Activity and Blood Glucose Levels Among Adults with Type 2 Diabetes Attending Meru Hospital, Meru County, Kenya. Kenyatta Univ; 2018.

35. Mugah MS, Muhati C. Socio-cultural dynamics influencing diabetes control: a case study of Vihiga District Hospital, Kenya. Int J Sci Res Innov Technol. 2016;3(2):139-159.

36. Atienojalang G, Tsolekile LP, Puoane T. Hypertension: do healthcare workers adhere to diabetes clinical care guidelines? A study at a National Hospital, Kenya. Hypertension. 2014;3(6):1-4.

37. Theuri AW, Makokha A, Kyallo F. Effect of using mobile phone communication on drug adherence of Type 2 diabetes mellitus patients at Kitui County Referral Hospital, Kenya. Int J Diabetes Res. 2019;8:(May):23-29.

38. Asenahabi E. Assessment of Treatment Compliance Amongst Adult Patients with Type Two Diabetes Mellitus at Kenyatta National Hospital. Univ Nairobi; 2014.

39. Mirghan HO. An evaluation of adherence to anti-diabetic medications among type 2 diabetic patients in a Sudanese outpatient clinic. Pan Afr Med J. 2019;34(34):1-9. doi:10.11604/pamj.2019.34.34.15161

40. Aminde LN, Tindong M, Ngwasiri CA, et al. Adherence to antidiabetic medication and factors associated with non-adherence among patients with type-2 diabetes mellitus in two regional hospitals in Cameroon. BMC Endocr Disord. 2019;19(35):1-9. doi:10.1186/ s12902-019-0360-9

41. Rathish D, Hemachandra R, Premadasa T, et al. Comparison of medication adherence between type 2 diabetes mellitus patients who pay for their medications and those who receive it free: a rural Asian experience. J Heal Popul Nutr. 2019;38(4):1-8.

42. Adisa R, Fakeye TO. Treatment non-adherence among patients with poorly controlled type 2 diabetes in ambulatory care settings in southwestern Nigeria. Afr Health Sci. 2014;14(1):1-10.

43. Rezaei M, Valiee S, Tahan M, Ebtekar F, Gheshlagh RG. Barriers of medication adherence in patients with type-2 diabetes: a pilot qualitative study. Diabetes, Metab Syndr Obes. 2019;589-599.

44. Awodele O, Osuolale JA. Medication adherence in type 2 diabetes patients: study of patients. Afr Health Sci. 2015;15(2):1-6. doi:10.4314/ahs.v15i2.26
Journal of Multidisciplinary Healthcare

\section{Publish your work in this journal}

The Journal of Multidisciplinary Healthcare is an international, peerreviewed open-access journal that aims to represent and publish research in healthcare areas delivered by practitioners of different disciplines. This includes studies and reviews conducted by multidisciplinary teams as well as research which evaluates the results or conduct of such teams or healthcare processes in general. The journal

\section{Dovepress}

covers a very wide range of areas and welcomes submissions from practitioners at all levels, from all over the world. The manuscript management system is completely online and includes a very quick and fair peer-review system. Visit http://www.dovepress.com/testimonials. php to read real quotes from published authors. 